$<$ 原 著 $>$

ヒト初代培養肝実質細胞の増殖制御

ーコラーゲン合成及び肝非実質細胞との関連一

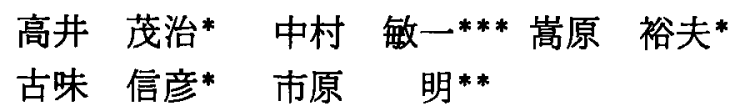

要 旨：肝再生調節機構を解明するため, ヒト初代培養肝細胞の DNA 合成を指標に検討した。 肝細胞は小肝組織片から灌流と振盪の 2 段階法によって分離した。肝実質細胞は血清無添加培 責液中で 3 週間単層を維持した。肝実質細胞はインスリンと表皮増殖因子（EGF）に応答して

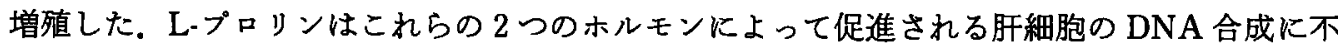
可欠であった. コラーゲン合成の特異的な阻害剂であるシスーヒドロキシプロリンは DNA 合 成を強く抑制した。このことから，肝細胞の増殖には内因性のコラーゲン合成が必要であるこ とが示唆された．肝実質細胞と肝非実質細胞を co-culture すると，L-プロリン，インスリン及 び EGF は肝非実質細胞の増殖を促進せずむしろ抑制する傾向が見られた. 即ら，これらの2つ のタイプの細胞の増殖の間には相反的な関係があることが示唆された。これらの結果は，肝再 生機構や肝線維化の機序を解明するのに有用であると考えられた。

真引用語：ヒト初代培養肝細胞増殖制御 コラーゲン合成 L-プロリン co-culture

はじめに

肝再生調節機構に関する研究は，基礎及び臨床肝臓 学において重要であり,現在まで数多く行われて来た。 しかし、その多くはin vivoでの研究であったため,多 くの要素が複雑に絡み合い, しかも個体差も大きく， 得られた結果の解积がしばしば困難で, 明確に結論で きないことが多かった。 そこで，これらの久点を補っ た in vitro の実験系として, 近年, 初代培着肝細胞系 が注目され，主にラット肝実質細胞を用いて，多くの 代謝調節やホルモン応答の研究がなされて来た ${ }^{1,22}$.さ らに最近, この系で成熟ラット肝紐胞の増殖が可能と なり, 肝再生の機構や增殖因子の研究が行われるよう になった。我々は既に in vitro の成熟ラット肝細胞が in vivo に匹敵する活発な肝機能を維持しており，多く のホルモンによく応答すること年, またこれらの細胞 はインスリンと表皮增殖因子（EGF）の存在下で活発 に增殖し, しかも cell-cell contact が增殖と肝細胞特

*徳島大学医学部第一外科学数室

** 徳島大学醅素科学研究センター

*.*. 九州大学理学部生物学科

<受付日'89年 4 月19日 $>$
有の機能発現との間の相反的な関保を調節しているこ とを見出した 1,9 6). また最近, ラット成熟肝細胞の増殖 には、コラーダン合成を介してL-プロリンが必要であ ることを見出した ${ }^{7)}$.さらに肝部分切除ラットの血清 中に hepatocyte growth factor (HGF) を見出し, こ れを部分精製しだ)。そして thrombin 処理をしたラッ ト血小板からこの factor を純化精製し,これが $69 \mathrm{KDa}$ と34KDa の heterodimeric protein であることを示し た9,10).

これらのラットで得られた知見は, ヒト肝䁍学の理 解の助けとはなるが, 直接当てはめることは出来ない. そこでラット肝細胞で得られた結果と比較しながら, ヒト初代培養肝細胞の研究を行ら必要が痛感された。 ヒトの知見は, 外科症例の肝切除後の回復や肝炎の修 復, 肝硬変, 肝癌発生機構の解明に有用である。 また ヒト肝炎ウイルスは敩密な種特異性を持っているた め, このウイルスの感染に対する研究，特にウイルス の同定や診断及び非 A 非 B 肝炎に対するワクチンの 開発にはヒト肝細胞を用いることが必要となる，また 今後その発展が期待される人工肝の開発にとっても有 用と考えられる。 
現在までにヒト初代培着肝細胞の報告はいくつか見 られる2,11 15). しかし，それらは汪とんど大量の肝実質 を要する大きな肝組織片からの分離方法とその培養方 法についてのものであり，增殖に対する研究の報告は 見られない。

そこで我々は，小さなヒト肝組織片からの肝細胞の 分離方法とその初代培養及びヒト初代培養肝細胞の増 殖制御について研究した結果を報告する。

\section{方 法}

\section{1. 肝実質細胞の分離}

ヒト肝組織片は，肝臓及び胆道系疾患患者で肝の病 理組織学的検查を必要とした症例の術中生㭘肝組織の 一部，あるいは坬立性の肝病変を摘除するために肝切 除した肝臓組織の一部が用いられた，22個の肝組織片 は全て湿重量 $1 \mathrm{~g}$ 以下であり，2 個の組織片が 1 つの切 断面を持っていたはかは全て 2 面以上の切断面を有し ていた。

得られた肝組織片は直ちに氷冷 Hank's 液（日水製 薬）中に浸し，速やかに培盖室に運ばれた。まず初め に0.5mM EGTA (Sigma) を含む $37^{\circ} \mathrm{C} の \mathrm{Ca}^{2+}$-free Hank's 液で 5 分間前灌流を行った。灌流は19 23 ゲージのカテーテルを付けた注射筒を用い，切断面の 脈管内に灌流液を用手的に注入することによって行っ た．次に灌流液を $0.05 \%$ コグナーゼ（和光純薬）と $1000 \mathrm{U} / \mathrm{m} l$ ディスパーゼ（合同酒精）を含む370の Hank's 液に変更し，灌流を続けた，そして約10分後， 組織片を 2 本の外科用メスを用いて径 $1 \mathrm{~mm}$ 以下の小 片に細切し，約 $10 \mathrm{~m} l$ の $0.05 \%$ コゲナーゼ含有 Hank's 液の中に浮避した。これを先太駒込めピペッ トを用いて 2 3 回静かにピベッティングを行った 後, 細胞浮遊液を $150 \mu \mathrm{m}$ pore size のメッシュフィル ターで虑過した，消化されずに残った沈殿物は，再度 $37^{\circ} \mathrm{C}$ の $0.05 \%$ コラゲナーゼ含有 Hank's 液に浮遊し， $100 \% \mathrm{O}_{2}$ 気相化したフラスコ内で 30 往復/分のゆっく りした速度で振燙を行った. 30分間振場した後これを 滤過した. 濾過後の細胞浮遊液は, 水冷 Eagle's minimal essential medium（以下 MEM）（日水製菜）を用 いて，50×g 2分間の遠心操作を 3 回行うことによっ て洗浄した。

\section{2. 肝実質細胞の単層培盖}

分離肝細胞を，5\%子牛血清 (Flow Laboratories)， $10^{-7} \mathrm{M}$ インスリン (Sigma) 及び10-6 $\mathrm{M}$ デキサメサン゙ ン(和光純薬)を添加した Leibovitz, L-15 medium (以 下 L-15 medium)（Flow Laboratories）に浮遊し，既
報の方法に従っでทット尾のコラーダンによって コーティングしたブラスチック皿に播いた.

細胞増殖の試験では， $5 \sim 8 \times 10^{4}$ 細胞 $/ \mathrm{cm}^{2}$ の細胞密 度で径 $24 \mathrm{~mm}$ の Linbro マルチブレートに播き，細胞 が培養㿼に接着した播き込み 4 時間後に培盖液を $5 \%$ 子牛血清, $10^{-9} \mathrm{M}$ インスリン及び $10^{-9} \mathrm{M}$ デキサメサジ ンを添加した L-15mediumに交換した。

長期間の培養試験では，細胞を $1 \times 10^{5}$ 細胞 $/ \mathrm{cm}^{2}$ 以上 の濃度で播き， 4 時間後に $5 \mathrm{U} / \mathrm{m} l$ のフブロチニン

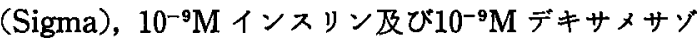
ンを添加した無血清 L-15 medium に交換した。 20時間 後に培地交換を行った後は，隔日に同培地によって培 地交換を行った。

\section{3. 肝実質細胞と肝非実質細胞の co-culture}

肝非実質細胞は，肝実質細胞の調整中に生じる上澄 み液を $200 \times \mathrm{g} て ゙ 5$ 分間遠心分離することによって得 た。この沈殿物を MEM を用いて 3 回遠心洗浄した。 この沈殿物は肝非実質細胞から成り，位相差顕改鏡に よって肝実質細胞が含まれていないことが確かめられ た。肝実質細胞を既に述べた方法で $5 \sim 8 \times 10^{4}$ 細胞/ $\mathrm{cm}^{2}$ の濃度で播き込及を行った 4 時間後に，3×104細 胞 $/ \mathrm{cm}^{2}$ の濃度で肝非実質細胞を同一血に播いた。培養 液は $5 \%$ 子牛血清, $10^{-9} \mathrm{M}$ インスリン及び $10^{-9} \mathrm{M}$ デキ サメサゾンを含む L-15 medium を用いた. 肝非実質細 胞の播き込み 2 時間後に培盖液を交換した。

\section{DNA 合成の分析}

細胞の播き込み24時間後に10-7 Mインスリンと20 $\mathrm{ng} / \mathrm{m} l$ マゥ в EGF (以下 $\mathrm{m}$-EGF) (Savage and Cohen らの方法 ${ }^{16}$ にしたがって雄マウス顎下腺より 精製した) を培養液中に加觉た。その12時間後に $\left[{ }^{3} \mathrm{H}\right]$ thymidine $(2.5 \mu \mathrm{Cu} / \mathrm{m} l)$ (New England Nuclear) を加えた。 $\left[{ }^{3} \mathrm{H}\right]$ thymidine を加えて36時間後に氷冷 phosphate buffered saline で 3 回洗浄を行った後 5 分 間 Gendre's solutionで固定した。この培盖㿼に Kodak nuclear trak emulsion, type NTB 2 (Kodak) をコーティングし，冷暗所で 7 日間露光後，既報の方 法4でオートラジオグラムの現像を行った。エオジン 染色を行った後これを写真撮影した，写真上の50個の ラざルされた細胞をかぞえた. labeling indexはラべ ルされた細胞の\%で表わした。

\section{5. アルフミンの免疫組織化学的染色}

培盖肝細胞のアルブミンを既報の方法に従っで7) streptoavidin-biotin peroxidase 法によって染色し た. 


\section{成 績}

\section{1. ヒト初代培養肝細胞の維持と増殖}

分離肝細胞の収率と生存率を表 1 に示した。最も小

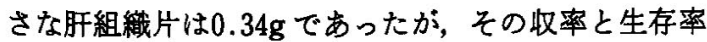
は, $5.58 \times 10^{6}$ 細胞 $/ \mathrm{g}$ と $93.4 \%$ であった。切断面が 1 面 だけの 2 例の肝組織片からは， 2 面以上の切断面を持 つ他の20例の肝組織片より高い収率 $\left(1 \times 10^{7}\right.$ 細胞/g) 方 得られた。生存率の平均は約 $85 \%$ であった。

表 2 はインスリンとデキサメサソンが細胞の培養血 への接着を増強することを示している.両者の共存下 では相加的な効果が見られ，接着率は無添加時の 2 倍

Table 1 Yield and Viability of Isolated Hepatocytes.

\begin{tabular}{lc}
\hline Yield & $6.4 \pm 3.3 \times 10^{6}$ cells/g wet weight \\
Viability & $86.5 \pm 7.3 \%$
\end{tabular}

Hepatocytes were isolated from specimens of 22 patients, 12 men and 10 women, aged 12 to $69 \mathrm{yr}$ (mean $53.6 \mathrm{yr}$ ). Viability was determined by the trypan blue exclusion test. Values are means \pm SD.
に増加した。

図 1 で示すように，肝細胞は1つの，時に 2 つの

Table 2 Effects of Insulin and Dexamethasone on the Attachment of Isolated Hepatocytes.

\begin{tabular}{l|c}
\hline \multicolumn{1}{c|}{ Addition } & Attachment (\%) \\
\hline None & $28.5 \pm 1.3$ \\
Insulin $\left(10^{-7} \mathrm{M}\right)$ & $39.5 \pm 4.2$ \\
Dexamethasone $\left(10^{-7} \mathrm{M}\right)$ & $36.8 \pm 4.6$ \\
Insulin $\left(10^{-7} \mathrm{M}\right)+$ Dexamethasone $\left(10^{-7} \mathrm{M}\right)$ & $51.8 \pm 4.3$ \\
Insulin $\left(10^{-7} \mathrm{M}\right)+$ Dexamethasone $\left(10^{-6} \mathrm{M}\right)$ & $54.5 \pm 1.0$ \\
\hline
\end{tabular}

Hepatocytes were obtained from a 55 yr old female. The isolated hepatocytes were suspended in L-15 medium supplemented with $5 \%$ calf serum, $10^{-9} \mathrm{M}$ insulin and $10^{-9} \mathrm{M}$ dexamethasone. Cells were inoculated at $6 \times 10^{4} \mathrm{cells} / \mathrm{cm}^{2}$ and hormones were added as indicated at the time of inoculation. The medium was changed 4 h later. Cell attachment was determined after culture for $24 \mathrm{~h}$ with two medium changes. For calculation of the attachment efficiency, the cells were photographed and the number of attached cells in the photograph was counted. The attachment efficiency is expressed as the number of attached cells as a percentage of the number inoculated. Values are means \pm SD for triplicate plates.

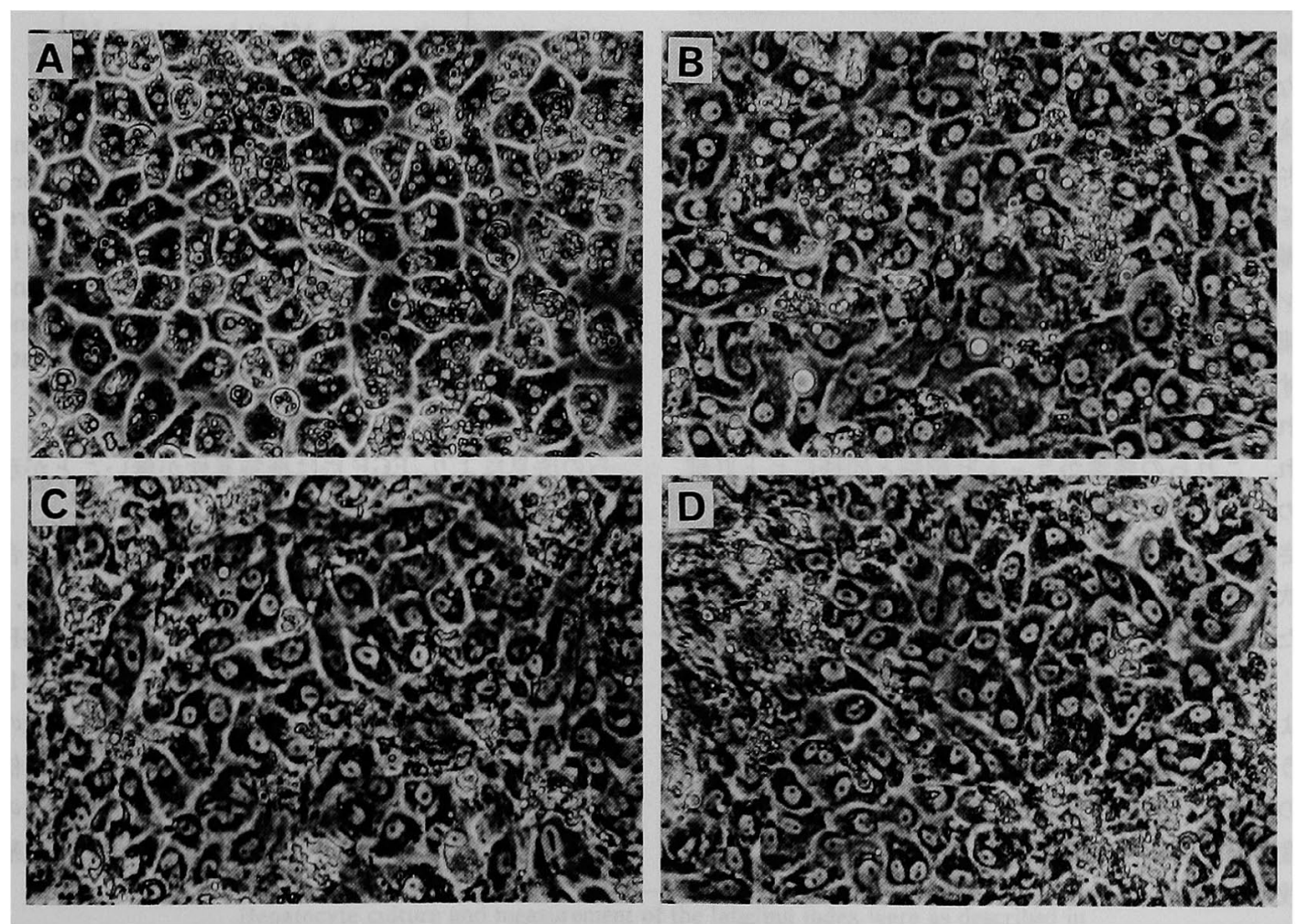

Fig. 1 Phase-contrast photomicrographs of primary cultures of hepatocytes $(X$ 156), A : 1 day, B : 7days, C: 14days, D : 21days. 


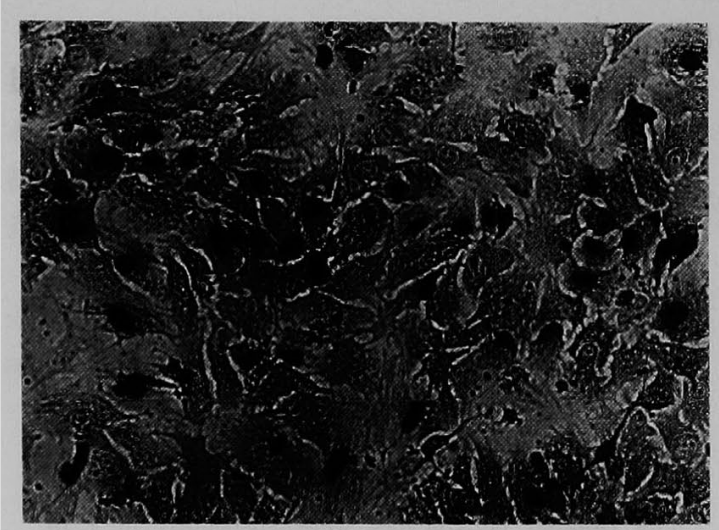

Fig. 2 Autoradiograph of hepatocytes $(\times 240)$. Hepatocyte culture and autoradiography were as described in Methods. L.Proline $(30 \mathrm{mg} / \mathrm{L}$ ) was added at the same time as insulin and m-EGF.

形の核を有し，細胞質はおそらく脂肪滴と考えられる いくつかの顆粒を有していた，飽和密度に近い高細胞 密度でラット初代培養肝細胞は 1 週間しか単層を維持 できず18)，その後きわめて少数混在する非実質細胞が 増殖し始めた。これに対しヒト肝細胞は， 3 週間単層 を維持した。 3 週以後に肝非実質細胞が見られるよう になった。これらの成熟初代培養肝細胞は mitogen 加えなければ静止状態を維持した。

ヒト肝細胞の培養における我々の主な興味はその增 殖に適した条件を見出すことである。ラット肝細胞の 増殖に対する条件占を考慮に入れ，まず我々はインス リン, EGF及びL-プロリンの存在下でヒト初代培盖 肝細胞の DNA 合成が誘導されるかどうかをオートラ シオグラフィを用いて検討した。図2で示したように， これらの要素の存在下では多くの肝細胞の核がラベル され，これらの要素がラット肝細胞と同様にヒト肝細 胞の DNA 合成の誘導にとっても効果的であることが 示された。

次に我なは，m-EGF と遗层子組替えによって得ら れたヒト EGF（以下h-EGF）（フース製薬より供与） の，ヒト肝細胞の DNA 合成に及ぼす効果を見ること によって EGF の種特異性を検討した，図 3 に示した ように, 低濃度では $\mathrm{m}-\mathrm{EGF}$ す $\mathrm{h}-\mathrm{EGF}$ む共にヒト旰細 胞の DNA 合成を用量依存的に促進した。いずれも高 濃度ではその効果は減少した。

我々はまた，成熟ラット肝細胞の DNA 合成に及ぼ す $\mathrm{m}$-EGF と h-EGF の効果を検討した. その結果, 七 ト肝細胞に対するすのと同様の結果が得られた。これ
30巻10号 (1989)
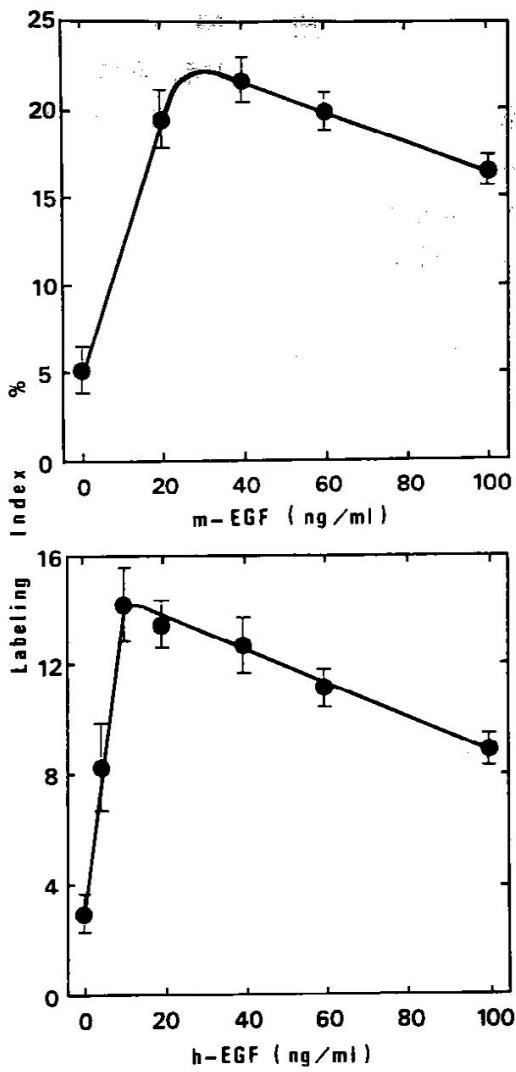

Fig. 3 Dose-dependence of effects of $m-E G F$ and $\mathrm{h}$-EGF on DNA synthesis in hepatocytes in primary culture. Hepatocyte culture and measurement of the labeling index were as described in Methods. Various concentrations of m-EGF and h-EGF were added to cultures with insulin and proline. Values are means $\pm S D$ for triplicate plates.

らの所見により，EGFには種特異性が無いことが示さ れた。

次に我々は，ここで示したヒト肝細胞の DNA 合成 が細胞分裂につながっているかどうかを険討した，そ の結果図 4 に示したよらに,インスリンと m-EGFに 応答して培養 5 日後に細胞数は1.4倍に増加した。した がってヒト初代培盖肝細胞の DNA 合成は肝細胞の增 殖を表わしていることが示された。細胞数が約1.4倍に 増加後，増殖が停止することより，ラット肝細胞の培 盖において見られる cell-cell contactによる增殖制 御)が働いている可能性が示唆された。

この他のグルカゴン,トリヨードサイロニンや成長 ホルモン等のホルモンは有意義な DNA 合成の促進作 
用を示さなかった。

2. ヒト肝細胞の DNA 合成に及ほすコラーゲン合 成の効果

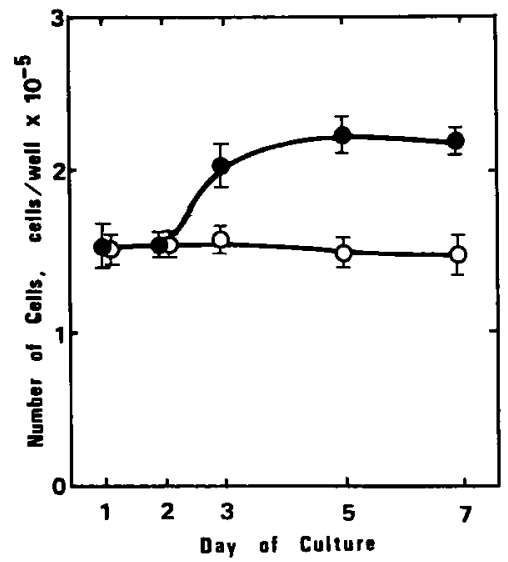

Fig. 4 Effect of insulin, m-EGF, proline and ascorbic acid on increase of cell numbers. Hepatocytes were inoculated at an initial density of $3 \times 10^{5}$ cells $/ 2.4 \mathrm{~cm}$ dish. The medium was changed to L-15 medium supplemented with $5 \%$ calf serum, $10^{-9} \mathrm{M}$ insulin and $10^{-9} \mathrm{M}$ dexamethasone $4 \mathrm{~h}$ after cell inoculation and renewed $20 \mathrm{~h}$ later and then once every two days. After 1, 3 and 5days culture, insulin $\left(10^{-7} \mathrm{M}\right), \mathrm{m}-\mathrm{EGF}(20 \mathrm{ng} / \mathrm{m} l)$, L-proline $(30 \mathrm{mg} / \mathrm{L})$ and $\mathrm{L}$-ascorbic acid $(200 \mathrm{mg} / \mathrm{L})$ were added to half the cultures. For calculation of the number of cells, the cells were photographed on the indicated days and the number of cells in the photograph was counted. Values are means $\pm S D$ for triplicate plates. $O:$ no addition, 0 : with insulin, $\mathrm{m}$-EGF, $\mathrm{L}$-proline and L-ascorbic acid.
我々は，L-ブロリンが成熟ラット初代培養肝細胞の 増殖の誘導に必須であり,このL-ブロリンの効果はコ ラーゲン合成を介して働いていることを示しだ．そ こでヒト初代培養肝細胞の DNA 合成の誘導にとって もL-プロリンが必須であるかどらかを検討した. 表 3 に示したように, L-プロリンを含まない培地である L15 medium ではたとえインスリンと m-EGFを加えて も labeling index は非常に低かった。これにL-ブロリ ン $30 \mathrm{mg} / \mathrm{L}$ を加えると，15\%以上の肝細胞がインスリ ンと m-EGFに応答してラベルされた，L-プロリンは 単独ですある程度 DNA 合成を刺激した。このL-ブロ リンの効果がコラーゲン合成に関係していることを確 かめるために，コラーゲン合成の特異的阻害剤である cis-4-hydroxy-L-proline (以下 cis-OH-Pro) (Sigma) とコラーゲン合成促進剤であるフスコルビン酸（和光 純薬)の DNA 合成に対する効果を L-プロリンの存在 下で検討した. 表 3 に示したように cis-OH·Proは DNA 合成を完全に抑制し，またアスコルビン酸は DNA 合成を強く促進した。

この增殖を起こす条件下で，これらのヒト肝細胞は 肝細胞特有の機能，例えばフルブミン合成を維持して いる.このことは図 5 で示している免疫組織化学的染 色で証明された。

3. 肝実質細胞の増殖に対する肝非実質細胞の cocultureによる影辢

肝滅は実質細胞のみならず多くの非実質細胞から 成っている.したがって, 実質細胞と非実質細胞の間 の関係を研究することは重要である。この研究のため 我々は，実質細胞と非実質細胞を co-culture し，その 実質細胞の增殖に対する影響を検討した。四6に示し

Table 3 Effects of Insulin, m-EGF and Proline on DNA Synthesis in Primary Cultures of Hepatocytes.

\begin{tabular}{l|c|c}
\hline \multirow{2}{*}{ Addition } & \multicolumn{2}{|c}{ Labeling index (\%) } \\
\cline { 2 - 3 } & Exp 1 & Exp 2 \\
\hline None & not detectable & not detectable \\
Insulin $\left(10^{-7} \mathrm{M}\right)+\mathrm{m}-\mathrm{EGF}(20 \mathrm{ng} / \mathrm{m} l)$ & $1.8 \pm 0.4$ & $1.4 \pm 0.2$ \\
Proline(30mg/L) & $5.5 \pm 0.8$ & $6.0 \pm 1.1$ \\
Insulin+m-EGF+Proline & $17.8 \pm 3.0$ & $15.5 \pm 1.5$ \\
Insulin+m-EGF+Proline & & $29.3 \pm 3.1$ \\
+Ascorbic acid(200 mg/L) & & \\
Insulin+m-EGF+Proline & & not detectable \\
\hline +cis-OH-Pro(120 mg/L) & & \\
\hline
\end{tabular}

Hepatocyte culture and measurement of the labeling index were as described in Methods. The indicated compounds were added $24 \mathrm{~h}$ after start of the culture. Values are means $\pm S D$ for triplicate plates. 


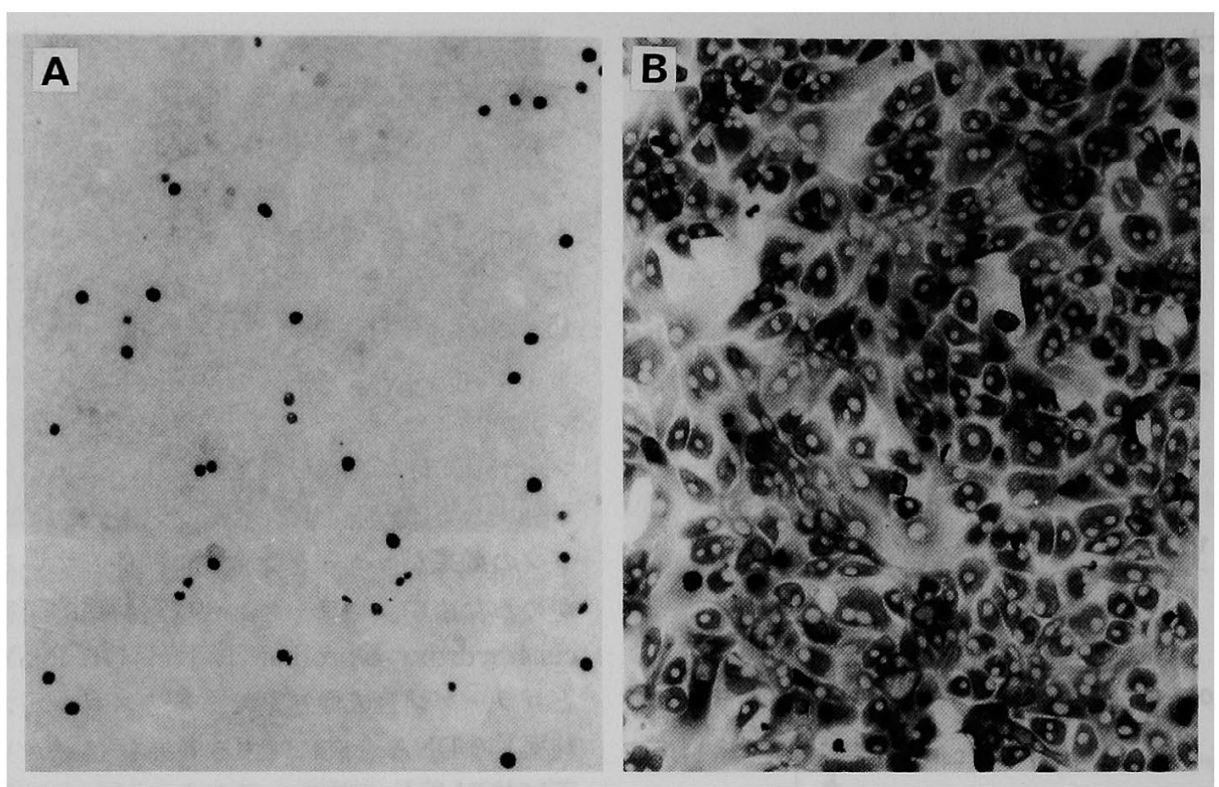

Fig. 5 Immunocytochemical staining of albumin and radioautgraphy of hepatocyte growth in primary culture $(\times 156)$. Hepatocytes were cultured in the presence of $10^{-7} \mathrm{M}$ insulin, $20 \mathrm{ng} / \mathrm{m} l \mathrm{~m} \cdot \mathrm{EGF}$ and $30 \mathrm{mg} / \mathrm{L} \mathrm{L}$-proline. Then $12 \mathrm{~h}$ later $\left[{ }^{3} \mathrm{H}\right]$ thymidine was added and $36 \mathrm{~h}$ later staining of albumin and radioautography were performed as described in Methods.

A : control serum, B : anti-albumin serum.

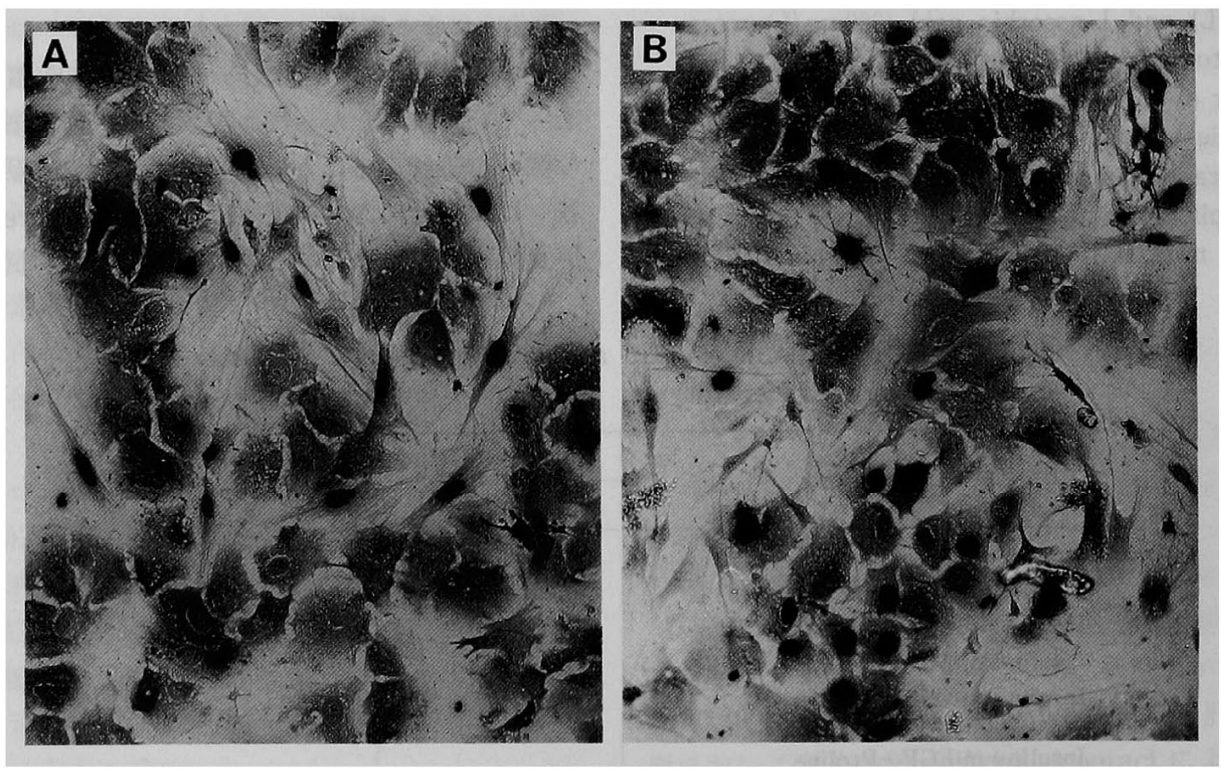

Fig. 6 Autoradiographs of parenchymal hepatocytes and non-parenchymal liver cells in co-culture $(\times 240)$. Co-culture and autoradiography were as described in Methods.

A : no addition, B : with insulin, m-EGF and L-proline. 
Table 4 Reciprocal Effects of Insulin, m-EGF and Proline on DNA Synthesis of NonParenchymal Liver Cells and Parenchymal Hepatocytes in Primary Co-culture.

\begin{tabular}{l|c|c|c|c}
\hline \multirow{2}{*}{ Addition } & \multicolumn{3}{c}{ Labeling index (\%) } \\
\cline { 2 - 5 } & \multicolumn{2}{|c}{ Exp 1 } & \multicolumn{2}{c}{ Exp 2 } \\
\cline { 2 - 5 } & $\begin{array}{c}\text { Non-parenchymal } \\
\text { liver cells }\end{array}$ & $\begin{array}{c}\text { Parenchymal } \\
\text { hepatocytes }\end{array}$ & $\begin{array}{c}\text { Non-parenchymal } \\
\text { liver cells }\end{array}$ & $\begin{array}{c}\text { Parenchymal } \\
\text { hepatocytes }\end{array}$ \\
\hline None & $10.2 \pm 0.4$ & not detectable & $26.4 \pm 2.2$ & not detectable \\
Insulin(10-7 M)+ & $7.3 \pm 0.5$ & $3.1 \pm 0.5$ & $26.8 \pm 4.1$ & $2.0 \pm 0.3$ \\
m-EGF(20 ng/ml) & $7.6 \pm 0.8$ & $9.3 \pm 1.1$ & $19.0 \pm 3.9$ & $6.4 \pm 0.6$ \\
$\begin{array}{c}\text { Proline(30 mg/L) } \\
\text { Insulin+m-EGF } \\
\text { +Proline }\end{array}$ & $6.9 \pm 0.8$ & $13.9 \pm 1.4$ & $20.7 \pm 1.3$ & $18.3 \pm 3.1$ \\
\hline
\end{tabular}

Methods for co-culture and measurement of the labeling index were as described in Methods. All compounds indicated were added 24 th after start of culture. Values are means \pm SD for triplicate plates.

たように,インスリン, m-EGF と L-プロリンが存在し ない培地では，線維芽細胞と考えられる肝非実質細胞 に多くラベルが見られ，実質細胞はラベルされなかっ た.これに対し、インスリン, m-EGF と L-プロリンを 加えると，非実質細胞のラベルは減少し，多くの実質 細胞がラベルされた。この定量的な結果を表 4 に示し た. 肝実質細胞の DNA 合成を誘導するインスリン, $\mathrm{m} \cdot \mathrm{EGF}$ と L-プロリンの添加は, 非実質細胞の DNA 合成を促進せず，むしろ抑制する傾向を示した。

\section{考 察}

ヒト肝細胞の分離方法については，既にいくつかの 報告が見られる.大別すると灌流法 ${ }^{11 \sim 13)}$,振蕰法 ${ }^{14,15)}$ である。今までに報告されている灌流法は，数 $\mathrm{g}$ 以上 の大きなしかる切断面が 1 面の肝組織片を用いて行わ れており，今回我々が用いた1g 以下の小さなしかる2 面以上の切断面を持つ肝組織片にはそのまま適用出来 ない。このよらな小さな肝組織片に対しては今まで振 盪法が行われて来たが，振盪法による收率は灌流法に 比べると著しく低い。

そこで我々は，収率が高くしかも肝細胞の膜への障 害の少ない灌流法によってできるかぎり消化を行い， 未消化のまま残った組織に対して振崵法を加えるとい ら灌流法と振湯法を折克した方法を行った。

まず灌流を行うのに際し，肝組織片が小さいため肝 組織片を固定してボンプを用いて行らといら方法は不 可能であった。 そこで肝組織片を手の上に乗せて，注 射筒を用いて用手的に行った，灌流法によってよく消 化するためには切断面が 1 面であることが必要であ る.なぜなら切断面が 2 面以上あると，注入された醉 素液は肝組織片全体に十分浸透して消化作用を行う前 に，その多くが他の切断面から漏れ出てしまらからで
あるそこで消化されずに残った組織を振盪法によっ て消化したのであるが，さらに消化を助けるために， 灌流液としてコラゲナーゼ単独より強い消化作用を持 つコラゲナーゼとディスパーゼの混合液を用いた。こ の方法により我々は，小肝組織片から平均約 $85 \%$ とい ら高い生存率の肝細胞を比較的高収率で得ることがで きた。

分離肝細胞の膜が障害を受けると，たとえその細胞 が viableであっても細胞は培養皿へ接着することが 出来なかった。他の研究者らによって報告されている ように, ヒト肝細胞の接着率はラット肝細胞に比へ低 (11,15,19). このヒト肝細胞とラット肝細胞の接着率の 差は，ヒト肝組織がラットに比べ固く消化されにくい ために分離に要する時間が長くかかることや，機械的 操作による細胞膜の損傷によるものと考号られる。振 盪時の細胞膜の損傷をできるかぎり避けるために， 我々は30往復/分といら遅い速度で振望を行った。

細胞膜の接着率を高めるには，表 2 で示したように インスリンとデキサメサゾンが有効であった。 この所 見は成熟ラット肝細胞での結果と一致した ${ }^{18,199}$.

ラット肝細胞が 1 週間しか培養血上で単層を維持し なかったのに対し18)，ヒト肝細胞は３週間単層を維持 した，我々は培盖液として，ラット肝細胞の培盖に最 適の培地であったインスリンとデキサメサゾンを添加 した L-15mediumを使用した7”。培養液には血清は添 加しなかったが，培養血にはラット尾コラーゲンを コートした。これらの条件がラット肝細胞よりるヒト 肝細胞の長期生存にとって適していたことも考兄られ るが，犬や豚の肝細胞がラット肝細胞上り長期間単層 を維持することを考えると(未発表)，ラットとヒト肝 細胞の単層維持の時間の差は, 種の違いによる可能性 
も考えられた。

我々はこれらの培養条件の下で，七ト初代培湌肝細 胞が増殖することを見出した．しかしそれは一定の条 件，つまりインスリン，EGF及びL-プロリンが存在す るといら条件の下である。これらの増殖を起こす条件 下で我々は 2 つの興味ある結果を得た。そう 1 つは, コラーゲン合成が肝細胞の増殖に関与しているといら こと，ち51つは，肝実質細胞と肝非実質細胞の間の 増殖の関係である。

増殖に怙けるコラーゲン合成の関与は，L-プロリン の必要性, アスコルビン酸による増殖の促進及び cisOH-Proによる強い抑制効果などによって証明され た。この cis-OH-Proによる DNA 合成の抑制は, cisOH-Proの細胞毒性によるるのではない，なぜなら， ラット肝細胞でこの抑制物質は, 分泌及び細胞内蛋白 の合成を抑制しなかったし，また位相差顕徽鏡を用い た肝細胞の形態学的所見に上る判定でも細胞毒性を示 す所見は見られなかった。 また，cis-OH-Proによる増 殖の抑制は，培養液に過鄱の L-プロリンを加えること によって完全に除去された7!

今回の全ての実験はタイプI コラーゲンをコートし た培養㿼上で行われた。したがって外から加えられた タイプI コラーゲンは，増殖を促進するには不十分た と考えられる．現在どのタイプのコラーゲンが肝細胞 の增殖に必要なのかは不明である。しかしラット肝細 胞において，L-プロリンや cis-OH-Proは mitogen 加えた始めの12時間の間にだ影響を与えることを見 出した (未発表)。この所見は, コラーゲン合成が mitogenに反応する能力を生みだすためには, cell cycle の $\mathrm{G}_{1}$ 早期にコラーゲン合成が必要であること を示唆している.

我々はまた，肝実質細胞と肝非実質細胞のcoculture に拧いて, 肝実質細胞と肝非実質細胞の増殖の 相互の影響を観察した。我々は最近, ラット肝実質細 胞を肝非実質細胞と co-cultureすることによって, surface componentsを介して肝実質細胞の増殖が刺 激されることを見出しだ20).

Guguen-Guillouzo らは, 肝実質細胞と非実質細胞の co-culture が肝細胞の機能維持に重要であることを報 告している2!.しかし彼らは，ヒト肝実質細胞をラット 肝上皮細胞と co-culture したのであり，また肝細胞の 増殖に関しては観察していない，肝細胞の機能にとっ て細胞外基質の重要性を示唆している報告2)や，肝細 胞の増殖にコラーゲン合成が必要であるという我々の
所見は, 肝細胞の増殖が種々の mitogen だけでなく䏷 細胞の微細環境の要素によっても制御されていること を示している.

現在知られている肝䁍での細胞間物質は、コラーゲ ソ, ラミニン, フィプロネクチン及びプロテオダリカ ンでありここれらが互いに種々の異なった機能を発揮 するのに適した環境を作り出しているのであろう。こ れらの物質は肝組織の中の種々の細胞，つまり肝実質 細胞自身, 内皮細胞, 胆管細胞や線維芽細胞などによっ て作り出されていると推湘されている。

我々の研究も含め肝細胞の培盖に関する最近の研究 は，肝実質細胞間や肝実質細胞と肝非実質細胞の間の 相互作用，さらに細胞間マトリックスが肝細胞の活性 にとってたいへん重要であることを示している。した がって, 肝細胞の活性化の研究において, 組織構筑を 考慮した生化学的研究が肝の再生, 肝線維化の機序中 肝臟癌発生の機構を知る上に重要な情報を提供すると 思われる。

\section{結語}

1) コラゲナーゼとディスパーゼの混合液を用いた 灌流と振壍の 2 段階法によって, $1 \mathrm{~g}$ 以下の小さなヒ卜 肝組織片から高い生存率と収率の肝細胞を分離した。

2）ヒ卜初代培羡肝細胞は，飽和密度に近い、細胞密度 では 3 週間単層を維持した。

3）ヒト初代培盖肝細胞は，1/2飽和細胞密度でイン スリン及びEGFによって増殖が促進された。

4）上卜初代培養肝細胞の増殖には，L-プロリンが必 要であり,このL-ブロリンはュラーゲン合成を介して 働いていることが示焧された。

5）ヒ卜肝実質細胞之肝非実質細胞の co-culture で は, L-プロリン,インスリン及び EGF は肝非実質細胞 の增殖を促進せず，むしろ抑制する傾向が見られた。

本論文の要旨の一部は第21回日本肝㙎学会において発表 した.

\section{女 献}

1) Nakamura $T$, Ichihara A : Control of growth and expression of differentiated functions of mature hepatocytes in primary culture. Cell Struc Func 10:1-16, 1985

2) Guillouzo A, Guguen-Guillouzo C (eds): Isolated and Cultured Hepatocytes. John Libbey Eurotext, London, 1986

3) Tomita $Y$, Nakamura $T$, Ichihara A : Control 
of DNA synthesis and ornithine decarboxylase activity by hormones and amino acids in primary cultures of adult rat hepatocytes. Exp Cell Res 1̀35: 363-371, 1981

4) Nakamura T, Tomita $Y$, Ichihara A: Density-dependent growth control of adult rat hepatocytes in primary culture. J Biochem 94 : 1029-1035, 1983

5) Nakamura T, Yoshimoto $K$, Nakayama $Y$, et al : Reciprocal modulation of growth and differentiated functions of mature rat hepatocytes in primary culture by cell-cell contact and cell membranes. Proc Natl Acad Sci USA $80: 7229$ $-7233,1983$

6) Nakamura $T, N a k a y a m a ~ Y$, Teramoto $H$, et al: Loss of reciprocal modulations of growth and liver function of hepatoma cells in culture by contact with cells or cell membranes. Proc Natl Acad Sci USA 81 : 6398-6402, 1984

7) Nakamura $T$, Teramoto $H$, Tomita $Y$, et al : L-Proline is an essential amino acid for hepatocyte growth in culture. Biochem Biophys Res Commun $122: 884-891,1984$

8) Nakamura $T$, Nawa $K$, Ichihara A: Partial purification and characterization of hepatocyte growth factor from serum of hepatectomized rats. Biochem Biophys Res Commun 122 : 1450 $-1459,1984$

9) Nakamura $T$, Teramoto $H$, Ichihara A : Purification and characterization of a growth factor from rat platelets for mature parenchymal hepatocytes in primary cultures. Proc Natl Acad Sci USA 83 : 6489-6493, 1986

10) Nakamura $T$, Nawa $K$, Ichihara $A$, et al: Purification and subunit structure of hepatocyte growth factor from rat platelets. FEBS Lett 224 : 311-316, 1987

11) Strom SC, Jirtle RL, Jones RS, et al: Isola- tion, culture and transplantation of human hepatocytes. J Natl Cancer Inst 68: 771-778, 1982

12) Guguen-Guillouzo C, Campion JP, Brissot $P$, et al : High yield preparation of isolated human adult hepatocytes by enzymatic perfusion of the liver. Cell Biol Int Rep 6:625-628, 1982

13) Reese JA, Byard JL : Isolation and culture of adult hepatocytes from liver biopsies. In Vitro $17: 935-940,1981$

14) Miyazaki K, Takaki R, Nakayama F, et al: Isolation and primary culture of adult human hepatocytes. Cell Tissue Res $218: 13-21,1981$

15) Maekubo H, Ozaki S, Mitmaker B, et al: Preparation of human hepatocytes for primary culture. In Vitro $18: 483-491,1982$

16) Savage $C R$, Cohen $S$ : Epidermal growth factor and a new derivative. J Biol Chem 247 : 7609 $-7611,1972$

17) Nakamura $T$, Nagao $M$, Ichihara $A$ : In vitro induction of neonatal rat hepatocytes by direct contact with adult rat hepatocytes. Exp Cell Res $169: 1-14,1987$

18) Tanaka K, Sato $M$, Tomita $Y$, et al: Biochemical studies of liver functions in primary cultured hepatocytes of adult rats I. Hormonal effects on cell viability and protein synthesis. J Biochem 84 : 937-946, 1978

19) Horiuti $Y$, Nakamura $T$, Ichihara $A$ : Role of serum in maintenance of functional hepatocytes in primary culture. J Biochem 92 : 1985-1994, 1982

20) Shimaoka S, Nakamura T, Ichihara A : Stimulation of growth of primary cultured adult rat hepatocytes without growth factors by coculture with nonparenchymal liver cells. Exp Cell Res $172: 228-242,1987$ 


\section{Growth control of mature human parenchymal hepatocytes in primary culture: Relationships to collagen synthesis and non-parenchymal liver cells

\author{
Shigeharu TAKaI*, Toshikazu NAKAMURA**, Hiroo TAKEHARA*, \\ Nobuhiko KOMI* and Akira ICHIHARA**
}

Control of proliferation of human hepatocytes in primary culture was studied. Hepatocytes were isolated by a "two step" method (perfusion followed by shaking) from small specimens of human liver. The hepatocytes could be maintained in monolayer culture for three weeks in serum-free medium, and grew in response to insulin and epidermal growth factor (EGF). L-proline was essential for their DNA synthesis stimulated by these two hormones. Cis-hydroxyproline, a specific inhibitor of collagen synthesis, strongly inhibited DNA synthesis, suggesting that their growth required endogenous synthesis of collagen. In co-cultures of hepatocytes and non-parenchymal liver cells, addition of Lproline, insulin and EGF did not induce DNA synthesis in non-parenchymal liver cells and in fact rather suppressed their DNA synthesis, indicating a reciprocal relation between the growth of these two types of cells. These results should be useful in elucidating the mechanism of liver regeneration, and the pathogenesis of hepatic fibrosis.

* The First Department of Surgery, School of Medicine, The University of Tokushima (Tokushima)

** Institute for Enzyme Research, The University of Tokushima (Tokushima)

*** Department of Biology, Faculty of Science, Kyushu University (Fukuoka) 